\title{
PEMAKNAAN DAN PENGALAMAN SEBAGAI TRANSGENDER
}

\author{
Rosalina $^{1}$, Anindya Dewi Paramita ${ }^{2}$, Evanytha $^{3}$ \\ ${ }^{1,2,3}$ Fakultas Psikologi, Universitas Pancasila \\ ${ }^{I}$ Email: elinrosalina1999@gmail.com
}

\begin{abstract}
This study aims to get an overview of the meaning and experience of being transgender. This study use a qualitative research method, researcher conducted interviews with two subjects, one female to male transgender subject and one male to female subject. This research we will see how the dynamics that transgenders go through and feel. The description of meaning and experience as transgender is seen based on the dynamics that occur in the lives of each subject. The results showed that each subject had a discrepancy between their gender identity and their biological gender identity and had different fluctuations since childhood, continued to develop as adults, but both chose to cover up their gender identity for fear of the consequences. This research can be used for additional information on health administration and education in educating the public about transgender needs. The results showed that the two subjects had similar meanings but different experiences.
\end{abstract}

Keywords: transgender, meaning and experience, gender identity

\begin{abstract}
ABSTRAK
Individu transgender adalah individu yang identitas gendernya berbeda dengan jenis kelamin biologis yang terberi, sehingga pemaknaan terhadap identitas gender dengan jenis kelamin biologisnya juga mengalami perbedaan dan seringkali memberikan penglaman yang tidak sederhana bagi individu tersebut. Oleh karena itu, tujuan dari penelitian ini adalah untuk mengetahui gambaran pemaknaan dan penglaman sebagai seorang transgender. Pendekatan kualitatif dilakukan terhadap satu orang transgender female to male dan satu orang transgender male to female yang dipilih secara purposive. Data untuk penelitian ini diperoleh dari wawancara semi terstruktur. Hasil penelitian menunjukkan bahwa kedua subjek memiliki pemaknaan yang serupa namun pengalaman yang berbeda.
\end{abstract}

Kata Kunci: transgender, pemaknaan dan pengalaman, identitas gender

\section{PENDAHULUAN \\ Latar Belakang}

Standar pengaturan diri secara deskriptif untuk menentukan bagaimana seseorang mengakui bahwa diri mereka laki-laki atau perempuan disebut dengan identitas gender. Menurut Crooks dan Baur (2005) identitas gender merupakan perasaan subjektif yang dimiliki seseorang untuk menjadi laki-laki atau menjadi perempuan. Identitas gender juga mencerminkan ciri, fungsi, dan perasaan maskulinitas atau feminitas yang diperoleh dalam proses sosialisasi. Melalui proses interaktif ini, subjek secara sosial mengakui bahwa diri mereka adalah laki-laki atau perempuan. Ketika peran gender diterima oleh individu, maka akan ditanamkan pada konsep diri mereka secara pribadi, dan setiap individu memiliki perbedaan dalam menerima aturan normatif tentang laki-laki dan perempuan, berarti terdapat perbedaan masing-masing individu pada sejauh mana mereka memasukkan budaya gender ke dalam identitas pribadi mereka. Sejalan dengan pendapat Baron dan Byrne (2004) bahwa beberapa individu memiliki perbedaan dalam memaknai identitas gendernya dengan jenis kelaminnya secara biologis. Individu yang memiliki memiliki perbedaan antara identitas gender dengan jenis kelamin secara biologis akan menggunakan identitas yang sesuai sebagai standar untuk perilaku mereka (Leary dan Hoyle, 2009).

Ketidaksesuaian antara identitas gender yang dimiliki dengan jenis kelamin secara biologis dirasakan oleh transgender, menurut Afrasiabi dan Junbakshs (2019) mengatakan bahwa transgender tidak melupakan identitas jenis kelamin biologis mereka, sehingga transgender memilih untuk menggunakan beberapa strategi untuk membuat mereka merasa nyaman dengan kebutuhan mentalnya, seperti menampilkan identitas yang berlawanan dengan jenis kelamin 
biologis dan menampilkannya dalam kesendirian, serta mengidealisasikan diri dengan cara mengkhayal. Menurut Taylor (2009) seorang transgender secara psikologis berbeda dengan jenis kelamin biologisnya dan merasa tidak nyaman dengan kondisi tubuhnya. Transgender merasa bahwa dirinya memiliki jiwa dan fisik yang berbeda dan merasa bahwa jiwanya terjebak pada tubuh yang salah, perubahannya dapat terjadi dari female to male atau male to female (Stieglitz, 2010).

Konflik yang dialami oleh transgender adalah ketidaksesuaian psikologis gender dengan jenis kelamin biologisnya, transgender merasa terjebak pada tubuh yang salah sehingga berusaha menyelaraskan perasaan psikologis tentang identitas gender dan seks fisiknya melalui pakaian, riasan wajah, perilaku, hormon dan pembedahan, namun sebagian dari transgender tidak menjalani operasi pembedahan kelamin, mereka lebih memilih untuk memodifikasi bagian tertentu dari tubuh mereka seperti payudara atau beberapa bagian wajah, ada pula yang mengabaikan perubahan fisik dan hanya fokus pada modifikasi status sosial serta kedudukan hukum mereka, Bilodeau (2005 dalam Diamond 2011). Diamon (2011) melanjutkan bahwa transgender yang tidak merubah apapun kondisi fisiknya bukan berarti menerima jenis kelamin biologisnya, namun sebagai solusi agar tidak memiliki pengalaman kesusahan atau ketidanyamanan yang dihadapi.

Sebagai bentuk keberaniannya menghadapi dunia luar, beberapa dari transgender terdapat sesekali atau secara rutin menampilkan diri sebagai gender yang berlawanan dari jenis kelamin biologisnya. Menurut mereka, mendobrak norma merupakan cara untuk meraih kebebasan dan cara untuk mengekspresikan identitas sesksual mereka kepada dunia luar (Hartoyo, 2014). Dalam kehidupan sosial transgender sulit untuk mengekspresikan dirinya sebagai identitas yang berlawanan sehingga banyak transgender yang menggunakan identitas non-biner dengan tidak mengakui identitas gendernya secara spesifik, dan memilih untuk tidak menjalani terapi hormon atau melakukan operasi untuk menetapkan identitas gender mereka, Kuper, 2012 (dalam Katz, 2017).

Ketidaksesuaian gender dapat menyebabkan seseorang menjadi korban kejahatan dan mendapatkan diskriminasi (Lombardi, Wilchins, Priesing, \& Moulof, 2001). Seseorang yang merasa kebingungan dengan identitasnya akan menjadi tertekan dan kurang percaya diri, untuk itu mereka pun kesulitan dalam menentukan suatu tujuan, mereka juga akan lebih memilih diberikan label sebagai orang yang memiliki identitas negatif dibandingkan tidak memiliki identitas sama sekali (Erikson dalam Shaffer, 2005). Banyak transgender memilih untuk menyembunyikan identitasnya pada masyarakat luas untuk mempertahankan status sosial, domestik, dan ekonomi mereka (Afrasiabi dan junbakhsh, 2019).

Stigma sosial didapatkan oleh transgender seperti viktimisasi fisik langsung yang menimbulkan ancaman utama bagi kesehatan mental serta fisik. Lebih lanjut model stres minoritas yang dipaparkan oleh Meyer (2003 dalam Diamon, 2011) menunjukkan bahwa minoritas seksual dapat memunculkan stresor lingkungan seperti kekerasan verbal atau fisik, diskriminasi, pelecehan interpersonal dan pengasingan sosial secara umum yang mana dapat memberikan stres psikologis dan berdampak negatif pada kesejahteraan mental dan fisik, dapat dikatakan fungsi individu secara sosial dapat terganggu.

Menghadapi tekanan diskriminatif dari lingkungan sekitar termasuk keluarga, membuat transgender mengalami tekanan secara psikologis dan kesehatan. Pertanyaan- pertanyaan yang dilayangkan pada diri seorang transgender sering kali berbunyi tentang identitas mereka, termasuk pertanyaan apakah mereka benar-benar laki-laki atau perempuan, kebingungan itulah yang seringkali membuat trangender mengalami masalah psikologis yaitu anxiety disorder, mood disorder, sampai depresi, hal ini sejalan dengan penelitian yang di lakukan oleh King (2003) yaitu dari 277 partisipan, sebanyak 44 persen mengalami anxiety disorder, sumber kecemasan 
yang di miliki transgender berasal dari stress akibat perlakuan lingkungan.

Berdasarkan permasalahan di atas, perlu dipelajari lebih dalam bagaimana pemaknaan dan pengalaman identitas pada transgender agar bisa dipahami oleh transgender itu sendiri dalam menghadapi proses pemahaman diri dan perasaan yang nyaman. Jika melalui proses dan pemahaman dengan nyaman, maka dapat menjadi individu yang lebih sehat secara psikologis maupun fisik. Dalam bidang psikologi pemaknaan dan pengalaman identitas gender pada transgender dapat memberikan gambaran untuk kelas pendampingan secara profesional.

Pemaknaan dan pengalaman identitas pada kelompok transgender penting untuk dikaji agar memberikan gambaran secara mendalam dari pandangan psikologi untuk mengetahui bagaimana identitas gender sebagai jati diri transgender, selain itu dapat memberikan informasi orang tua dan anak-anak di awal masa kehidupan, dan pentingnya menyadari masalah yang mungkin terjadi pada usia anak-anak sehingga orang tua dapat mengidentifikasi dan memberikan perawatan yang sesuai. Hal ini tidak terlepas kaitannya untuk memberikan pemahaman keluarga bagaimana proses penyesuaian diri seorang transgender dalam kehidupannya, sehingga keluarga terdekat dapat mengetahui bagaimana seharusnya memperlakukan kelompok transgender. Penelitian ini dapat digunakan untuk menjadi bahan bacaan bagi keluarga sebagai lingkungan pertama dan harapan bagi transgender untuk memiliki informasi yang cukup tentang transgender.

\section{Rumusan Masalah}

Berdasarkan latar belakang yang dipaparkan, maka pertanyaan penelitian ini adalah bagaimana pemaknaan dan pengalaman sebagai transgender?

\section{METODE PENELITIAN}

Pendekatan Penelitian. Penelitian ini menggunakan metode penelitian kualitatif dengan pendekatan generic qualitative. Poerwandari (2011) menyatakan bahwa penelitian kualitatif memungkinkan pembacanya untuk memahami, mendalami, memaknai dan menginterpretasi terhadap bentuk asli suatu fenomena, penelitian kualitatif juga memberikan penekanan pada dinamika serta proses yang fokus pada variasi berbagai pengalaman dari individu maupun kelompok yang berbeda.

Subjek Penelitian. Teknik sampling pada penelitian ini menggunakan purposive sampling atau judgemental sampling, yang merupakan peneliti memilih responden penelitian yang dianggap memiliki informasi yang diperlukan serta bersedia untuk memberikan informasi tersebut (Kumar, 2011). Karakteristik partisipan yang menjadi subjek penelitian, yakni merupakan seorang transgender, antara male-to-female atau female-to-male yang berusia sedikitnya 18 tahun dan sudah menyelesaikan pendidikan SMA.

Teknik Pengumpulan Data. Teknik yang digunakan dalam penelitian ini adalah pedoman wawancara yang digunakan untuk mengingatkan peneliti terhadap aspek-aspek yang harus dibahas, dan menjadi alat untuk pengecekan apakah aspek tersebut sudah ditanyakan kepada subjek penelitian (Patton, 1990, dalam Poerwandari, 2013).

Teknik Analisis Data. Penelitian ini menggunakan teknik analisis data dengan melakukan koding, kategorisasi, dan tematisasi. Berikut Langkah-langkah teknik analisis data yang dilakukan:

1. Melakukan pengorganisasian data, dengan membuat verbatim atau transkip dari hasil wawancara.

2. Koding dan analisis, (Poerwandari, 2013) menyatakan bahwa koding yang dilakukan 
adalah untuk dapat mengorganisasi dan mensistematisasi data.

3. Setelah melakukan koding pada data, kemudian data disusun dan dikategorisasi berdasarkan kode-kode yang sudah diberikan.

4. Peneliti menentukan tema dalam penelitian.

5. Peneliti membuat uraian deskriptif mengenai data berdasarkan kategori yang telah dibuat, deskripsi dibuat dengan mendetail.

6. Peneliti melakukan interpretasi data dari uraian deskriptif yang dikaitkan dengan teori.

7. Peneliti membuat perbandingan antar partisipan penelitian dengan melihat persamaan dan perbedaan pada masing-masing kategori atau tema.

\section{HASIL DAN PEMBAHASAN}

Pelaksanaan Penelitian. Penelitian ini melibatkan empat orang subjek, dua subjek sebagai data primer, dua diantaranya sebagai data sekunder. Pengambilan data dilakukan pada akhir bulan Juni sampai awal bulan Juli pada tahun 2021, dilakukan wawancara mendalam terhadap semua subjek sedikitnya dua kali dan sebelumnya sudah melakukan rapport dan wawancara significant other satu kali dan sebelumnya sudah melakukan rapport.

\section{Partisipan 1: female-to-male}

Semasa hidupnya, SA beberapa kali memiliki keinginan untuk menjadi laki-laki dan terkadang bertanya-tanya mengapa dirinya tidak menjadi laki-laki, namun hal tersebut hanya datang sebentar dan setelahnya tidak terfikirkan lagi. Dirinya tetap menjalani kehidupan sebagai perempuan dengan pemikiran atau harapan jika memiliki kesempatan untuk terlahir kembali maka SA memilih untuk menjadi laki-laki. SA merasa jika menjadi laki-laki maka akan terdapat perbedaan yang tidak dapat diungkapkan olehnya. Meskipun demikian, SA memilih untuk menutupinya dari keluarga. SA sangat membatasi perilakunya sendiri saat berada di rumah, ia menjaga agar dirinya tidak bertindak di luar batas. Padahal SA sangat lelah jika membatasi perilakunya tersebut, dirinya sangat ingin menampilkan diri yang sebenarnya. SA menginginkan keluarganya menerima dirinya apa adanya, dan sangat wajar jika keluarganya terkejut namun dirinya ingin diterima sebagai diri sendiri.

"ada sih kaya beberapa kali pengen jadi cowok pengen jadi cowok tapi balik lagi kenapa engga cowok gitu kaya datang pergi datang pergi gitu” (SS1_144_P3)

Berbeda dengan perilaku saat berada di lingkungan keluarga, perilaku SA saat bersama temantemannya lebih terbuka. Saat berada di lingkungan keluarga maka SA akan cenderung tidak banyak bicara namun saat bersama dengan teman-teman yang cocok dengannya maka SA akan lebih terbuka. Ketika bersama dengan teman-temannya SA merasa lebih bebas untuk mengekpresikan diri yang sebenarnya karena SA tidak perlu menyembunyikan dirinya. Saat bersama teman-temannya, SA dapat secara terbuka membicarakan ketertarikan dirinya pada perempuan, dirinya akan menceritakan sedang dekat dengan sejenis dan teman-temannya mengerti akan hal itu.

Dukungan yang didapatkan SA berasal dari lingkungan pertemananya yang memiliki kondisi sama dengan SA yang mana penyuka sesama jenis, sehingga hal ini membuat SA lebih membuka diri dan termotivasi untuk terbuka sehingga SA dapat menjadi dirinya sendiri dan menunjukkan hal tersebut pada teman teman sekolahnya. Di samping itu, SA sering menonton konten yang dirasa sejalan dengan dirinya, dari hal ini lah SA mendapatkan kekuatan atau dukungan untuk dirinya sendiri. 


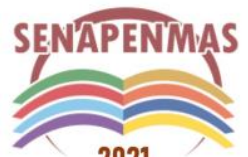

2021
Seminar Nasional Hasil Penelitian dan Pengabdian Kepada Masyarakat 2021 Pengembangan Ekonomi Bangsa Melalui Inovasi Digital Hasil Penelitian dan Pengabdian Kepada Masyarakat Jakarta, 21 Oktober 2021

"ada juga yang kaya gitu terus aku nanya ini pacar pacar kamu? Soal nya aku lihat kaya temen yang pada biasanya gitu di situ aku mulai ohh maksud nya udah ada yang berani gitu kan mulai dari situ mulai termotivasi mulai terbuka sama temen temen sekolah” (SS1_76_P2)

Dari segi penampilan fisik, SA memiliki rambut pendek dan berpakaiannya tidak seperti perempuan, dalam hal ini menurut SA orang terdekatnya menyadari bahwa SA tidak nyaman dengan dirinya yang sebenarnya. Meskipun untuk acara-acara formal yang diadakan oleh atau dihadiri bersama dengan keluarganya SA masih mengenakan pakaian semi-formal atau formal perempuan, seperti rok dan terusan, pada dasarnya SA merasa bahwa gaya berpakaian tersebut sangat berlawanan dengan dirinya yang lebih tercermin di kesehariannya atau ketika berkumpul bersama teman-temannya.

"ohh kalau untuk saudara ama tante aku ya kayaknya menyadari si kayak rambut aku pendek kayak gaya berpakaian aku kayak engga bisa engga bisa feminim gitu” (SS01_08_P1)

Sehari-hari, ketika sedang menyendiri atau berada di kamar, SA seringkali membayangkan dirinya menjadi laki-laki. Ia juga kerap bertanya-tanya mengapa dirinya tidak menjadi laki-laki saja. Dengan segala hal yang dialami dan terjadi pada dirinya, SA tetap memilih untuk menyembunyikan perilakunya karena merasa takut jika keadaan dirinya diketahui oleh keluarga, SA memikirkan konsekuensi yang mungkin diterimanya yakni tidak dianggap sebagai keluarga dan nantinya akan merasa malu. Ada pemikiran maupun perasaan bahwa keluarganya tidak akan bisa menerima kondisinya yang menyukai sesama jenis dan tidak bisa memahami keinginannya yang besar untuk menjalani peran laki-laki.

\section{Partisipan 2: male-to-female}

RA menerima jika dirinya dilahirkan sebagai laki-laki, namun sebelum itu dirinya pernah berfikir mengapa tidak menjadi perempuan. Terkadang dirinya berfikir jika menjadi perempuan maka akan berhasil menjalin hubungan dengan orang yang disukai, pasti sudah terjalin lama karena menurutnya hambatan hubungan RA hanya terhalang perihal dirinya adalah laki-laki.

"oke jadi aku kan engga pernah ada masalah kayak kenapa sih aku harus di lahirin sebagai laki laki, kana ada beberapa yang kaya gitu lin, aku tuh ngerasa dulu pas baru baru aku ngerealize gender aku, aku sempet berfikir kaya gitu” (SR2_162_P1)

RA tidak dapat memilih lebih nyaman menjadi dirinya saat di rumah atau saat berada di luar rumah, namun saat berada di luar rumah RA akan merasa lebih terbuka kerena saat berada di rumah RA akan tertutup. Ada perasaan bersalah yang besar di dalam diri RA terhadap versi dirinya yang diungkapkan ke hadapan keluarganya di rumah, karena merasa tidak sejujur versi yang diungkapkan ke teman-temannya atau lingkungan di luar rumah.

Teman-temannya masih juga menunjukkan harapan agar RA masih bisa berubah dan "kembali". Meskipun demikian, RA masih diterima oleh teman-temannya dan masih juga mendapatkan dukungan atau dapat menjadikan teman-temannya tempat untuk bercerita.

Sewaktu kecil, RA bertanya-tanya pada diri sendiri mengapa dirinya memiliki jiwa dan fisik yang berbeda, namun saat itu dirinya tidak berfikir terlalu jauh karena belum mengerti sepenuhnya. Subjek banyak berfikir tentang bagaimana cara menyeimbangkan antara jiwa dan tubuhnya yang tidak sesuai, apa yang harus dirinya lakukan, harus memilih yang mana, dan harus bersikap seperti apa. Dalam hal ini RA bukan tidak nyaman menjadi laki-laki namun dirinya merasa jiwanya adalah perempuan bukan laki-laki, sehingga RA berusaha untuk menyeimbangkan antara jiwa dan fisiknya yang berbeda. Sejak kecil dirinya sudah merasakan 
demikian, dan pada saat itu dirinya berumur 10 tahun masih belum mengerti apa yang dirasakan dalam dirinya.

"Bingung sih apa yang aku rasain kayak yang aku yang sebenernya aku nih kenapa sih? Gitu loh kaya yang, tapi waktu karena waktu itu kecil jadi aku pikiran nya engga sejauh itu, bukan pertanyaan yang ada di pikiarn aku bukan yang, kenapa aku kaya gini? Ada seintip yang ada di pikiran aku itu tuh kaya yang, oh aku tuh kaya gini yah. Berati body aku kaya gini aku harus gimana yah? Aku tuh yang bingung gitu loh pas dulu tuh kaya yang antara aku tuh mau bersikap nya yang emang seharus nya kaya laki laki seharus nya atau aku tuh harus ngikutin jiwa aku gitu loh" (SR2_170_P2)

RA terkadang membayangkan dirinya jika menjadi lawan jenis, seperti saat bercermin menggunakan kostum perempuan. RA menemukan gambaran bagaimana jika dirinya sebagai perempuan, namun untuk membayangkannya dapat dikatakan tidak terlalu sering.

"mmm kalu itu iya ada, pasti ada. Misalnya aku lagi pakai kostum tuh mau perfom biasa pakai kostum, aku kan biasa nya lihat cermin dulu, oh gini loh kalau aku jadi perempuan cantik ya, aku tuh kaya yang engga tau mungkin aku percaya diri nya engga tau diri mungkin kaya yang aku tuh kalau bercemin tuh kaya yang watch a $b^{*}$ tch in the mirror gitu loh"(SR2_179_P2)

RA sangat membatasi dirinya saat berada di rumah, subjek tidak ingin ke depannya nanti membuat ibunya kecewa, walaupun RA sendiri belum tahu apakah ibunya akan menerima atau akan menyimpan perasaan kecewanya seorang diri. RA memilih untuk menyembunyikan diri yang sebenarnya di hadapan ibunya untuk menjaga perasaan ibunya agar tidak kecewa karena RA menyadari pasti ibunya akan merasakan sakit jika mengetahui diri RA yang sebenarnya.

"tapi kalau untuk keluarga aku tuh lebih aku tuh engga mau nyakitin mereka gitu loh karena kan engga semua tuh bisa di terima kaya orang tua tuh, aku yakin sih kalau untuk orang tua engga ada orang tua yang bakal buang anak nya gitu aja, ibarat nya tuh kaya yang gimana pun kondisi anak nya orang tua itu pasti bakal terima, kalau kayak yang, giamna pun orang tua pasti bakal tetep sayang, cuma aku tuh kaya yang aku tuh sadar kalau misal nya itu tuh pasti ada saat nya mamah aku tuh sakit gitu loh kalau tau sebenernya. oh kok anak aku gini sih gitu ibarat nya" (SR2_20_P2)

Pada subjek RA terdapat temuan tema lain yang muncul yakni kondisi spiritualnya. RA menganut ajaran agamanya dan menganggap bahwa kedekatannya dengan Tuhan tersebut merupakan pertolongan agar mempertahankan fisiknya sebagai laki-laki walaupun jiwanya perempuan. RA pun tidak memiliki keinginan untuk melakukan operasi kelamin karena memegang kokoh ajaran agamanya.

"nah pas masuk smp itu aku realize, realize banget soal orientasi aku soal identitas gender aku di smp aku tuh mulai yakin kalau aku itu sebenernya... gimana ya bilang nya kaya gini loh fisik aku tuh laki laki tapi perasaan aku itu perempuan gitu jadi karena aku image ya jadi aku tuh muslim tuh jadi aku tuh masih ee bukan terhambat ya aku ngga bilang terhambat jadi ini tuh pertolongan dari tuhan dari Allah jadi aku laki laki nih sekuat apapun jiwa aku perempuan aku tuh tetep ngga bolehjadi perempuan jadi aku tuh di ibaratkan sampai operasi kelamin ga kepikiran sejauh itu gitu loh, kalau orang kan beda beda ada yang mau sampai ke situ" (SR2_169_P1) 


\section{Analisis Inter Subjek}

Jakarta, 21 Oktober 2021

Berdasarkan tema-tema yang muncul dapat dikatakan bahwa subjek SA dan RA memiliki penghayatan identitasnya masing-masing. Selain itu, tema lain yang muncul berkaitan dengan penghayatan identitas.

Mengenai Attempts to Display Desired Identity, subjek SA dan RA memiliki kesamaan yakni ingin menampilkan identitas yang dimiliki sebenarnya, namun hal ini disembunyikan dari keluarga. Subjek SA ingin menjadi laki-laki lantaran menurutnya hidup sebagai laki-laki lebih mudah, sedangkan subjek RA ingin menjadi perempuan karena akan lebih mudah bersama dengan orang yang disukainya. Sejak kecil subjek SA dan RA memang lebih sering bermain dengan permainan lawan jenis, subjek SA bermain bola dan sering bermain dengan laki-laki karena di lingkungannya lebih banyak ditemukan anak laki-laki dibandingkan perempuan, sedangkan subjek RA menyukai bermain berbie dan membuat sepatu kaca dengan gelas plastik. Kedua subjek lebih nyaman bermain permainan lawan jenis. Dibalik itu semua, subjek SA dan RA sama sama menyembunyikannya dari keluarga. Subjek SA dan RA sama sama menyembunyikan perilakunya jika berada di rumah.

Mengenai performing identity in solitude, subjek SA dan RA akan menjadi diri sendiri jika bersama dengan teman-temannya, jika berada di rumah maka akan memodifikasi perilaku yang sebenarnya. Subjek RA akan menunjukkan sisi lain dirinya dengan bersikap seperti laki-laki normal pada umumnya dan subjek juga mengubah suara jika berada di rumah. Berbeda saat bersama dengan teman-temannya, subjek RA akan menjadi dirinya sendiri dan tidak sungkan untuk menunjukkan orientasi seksualnya. Begitupun subjek SA akan menyesuaikan ekspresi jika melihat lawan jenis, dirinya akan mengeluarkan ekspresi menyukai padahal sebenarnya subjek merasa biasa saja melihat lawan jenis. Saat bersama dengan teman-temannya subjek juga akan menjadi dirinya sendiri, subjek akan terbuka tentang orientasi seksualnya. Subjek RA akan merasa percaya diri jika memakai baju perempuan dengan tidak ada orang lain yang melihatnya, subjek RA sangat menyadari penilaian orang-orang jika melihat dirinya memakai baju perempuan.

Pada Prominence of Identity, untuk menunjukkan identitasnya subjek SA memperhatikan orangorang disekitarnya, terdapat dari mereka memandang aneh SA karena lebih sering bermain dengan laki-laki. bentuk dukungan yang diterima berasal dari teman-temannya yang memiliki keadaan sama dengan subjek, dukungan lain juga diterima SA dari saudara sepupunya yang juga memiliki keadaan sama dengan subjek, hal ini membuat subjek lebih terbuka untuk menunjukkan identitas yang sebenarnya. Begitupun dengan subjek RA yang sangat memperhatikan bagaimana orang-orang sekitar menilainya sehingga dirinya cenderung menutup diri, dukungan yang diterima subjek berasal dari kakak laki-lakinya yang memiliki keadaan sama dengan subjek. Subjek SA dan RA memiliki kesamaan pada bentuk dukungan yakni dari orangorang yang memiliki keadaan sama dengan diri subjek.

Berbicara mengenai converse body dimana subjek RA sempat bingung dengan kondisinya yang memiliki jiwa perempuan sedangkan fisiknya laki-laki, subjek bingung untuk memilih mengikuti jiwanya atau mengikuti fisiknya, namun untuk saat ini dirinya dapat memisahkan anatar jiwa dan tubuhnya. Pandangan RA pada perempuan seperti memiliki kesamaan namun berbeda fisik, RA tidak pernah memiliki pengalaman buruk dengan laki-laki maupun perempuan, dirinya menyukai laki-laki karena secara natural merasa bahwa dalam dirinya adalah perempuan dan sangat sulit jika memiliki hubungan romantis dengan perempuan. RA tidak menyukai semua laki-laki namun saat dirinya menyukai sejenis, RA akan melihat dari bentuk perhatian serta perilaku yang baik terhadap dirinya, dan bukan semata-mata dari fisik yang terlihat.

Pada subjek SA merasakan kebingungan tentang kondisi dirinya yang lebih menyukai hal-hal yang digemari laki-laki. Pengalaman subjek SA terhadap laki-laki dapat dikatakan tidak baik, 
dimana dirinya sering melihat laki-laki melakukan hal-hal kasar pada perempuan, sehingga saat memiliki perasaan dengan perempuan maka subjek akan memiliki perasaan ingin melindungi, dan saat dirinya tidak dapat memiliki hubungan romantis dengan laki-laki karena memiliki ketakutan bagaimana jika laki-laki tersebut memperlakukan dirinya tidak baik. Pada hubungan pacaran, subjek akan memposisikan dirinya sebagai dominan.

Berbicara mengenai perilaku daydreaming, subjek SA terkadang membayangkan dirinya menjadi laki-laki, dirinya sering berfikir kenapa tidak menjadi laki-laki. subjek membayangkannya disaat saat tertentu seperti di jam dua atau di jam tiga dini hari. Setelah membayangkan hal tersebut, dirinya seringkali sampai menangis, dan tidak ada yang mengetahui tentang keadaannya pada saat itu. Berbeda dengan subjek SA, subjek RA membayangkan dirinya menjadi perempuan saat memakai kostum perempuan, dirinya akan merasa percaya diri saat memakai kostum perempuan saat tidak ada yang mengetahuinya.

Pada the pressures of coexistence, subjek RA menutup diri di rumah agar tidak menyakiti ibunya, walaupun subjek mengetahui bahwa ibunya menyadari subjek memiliki orientasi yang berbeda, namun subjek tetap memilih untuk tidak membicarakannya karena khawatir hal tersebut dapat menyakiti perasaan ibunya. Subjek pun sangat membatasi perilakunya saat di rumah, subjek akan menjadi laki-laki yang sewajarnya jika berada di rumah, berbeda saat subjek bersama dengan teman-temannya. Alasan lain subjek menyembunyikan identitas dan orientasi seksualnya karena takut akan membuat ibunya kecewa yang kedua kali, kaka laki-laki subjek sudah terbuka tentang identitas yang sebenarnya dan hal itu menyakiti perasaan ibunya, sehingga subjek memilih untuk menutup diri karena takut ibunya kecewa kembali terhadap anak-anaknya. Berbeda alasan dengan subjek RA, Subjek SA memilih untuk menutup identitasnya agar tidak dicurigai oleh orang-orang rumah. Subjek SA memikirkan konsekuensi jika dirinya terbuka, subjek takut tidak dianggap oleh keluarga, hal tersebut dapat dikatakan hukuman terberat di keluarganya. Saat menyembunyikan identitasnya, sebenarnya subjek merasa tertekan karena seringkali menahan diri untuk tidak menampilkan ekspresi yang sesungguhnya. Subjek tidak memotong habis rambutnya karena takut akan konsekuensi tersebut, subjek juga terkadang memakai baju perempuan hanya agar tidak dicurigai, padahal perasaan yang sebenarnya subjek sangat tidak nyaman.

Berbicara mengenai hubungan keluarga, pada subjek RA lingkungan keluarganya dapat dikatakan cukup hangat, dirinya memang tidak mendapatkan sosok ayah karena ayahnya sudah meninggal sejak subjek berusia 2 tahun, lalu ibunya menikah kembali setelah 10 tahun namun pernikahan tersebut tidak bertahan lama dan ayah sambung subjek memilih untuk meninggalkan rumah, sehingga subjek tidak memiliki sosok ayah hingga saat ini, walaupun demikian hubungan subjek dengan ibunya sangat baik, subjek pun sangat menyayangi adik-adiknya, subjek juga sangat dekat dengan kakak laki-lakinya walaupun kaka laki-lakinya sudah tidak tinggal bersama dengan subjek.

Sangat kontras dengan subjek RA, subjek SA tidak dekat sama sekali dengan keluarganya, sejak kecil subjek sudah sering diasuh oleh tantenya. Subjek memiliki kakak laki-laki kandung, ibu subjek meninggal saat subjek duduk di bangku SMA dan satu tahun kemudian ayahnya menikah kembali dengan membawa 2 anak. Namun subjek tidak pernah akrab dengan kakaknya dan adik sambungnya, hal ini karena mereka tinggal berjauhan dan masing-masing tidak dekat.

\section{KESIMPULAN DAN SARAN}

Berdasarkan hasil penelitian yang dilakukan terhadap SA dan RA, dapat disimpulkan bahwa transgender male-to-female dan female-to-male menjalani dan memaknai peran gender di dalam kehidupannya secara hampir serupa. Baik SA maupun RA memendam keinginan yang sangat 
besar untuk bisa hidup dengan identitas yang benar-benar menggambarkan dirinya dan mengungkap identitas yang "sesungguhnya". Identitas dirinya yang sebenarnya hanya benarbenar diketahui oleh dirinya. Keduanya masih hanya membuka diri sepenuhnya di lingkungan pertemanan yang bisa menerima mereka apa adanya. Baik SA maupun RA sama-sama kerap membayangkan kondisi dimana mereka dapat menjalani peran identitas gender yang diinginkannya secara bebas dan terbuka.

Kedua subjek memiliki ketidaksesuaian pada identitas biologisnya, baik SA maupun RA merasa nyaman jika berperan menjadi identitas gender yang berlawanan, keduanya akan bebas menunjukkan jati diri yang sebenarnya jika berada di luar lingkungan rumah. Perasaan tidak nyaman ini dimulai sejak mereka kecil dan semakin berkembang saat dewasa, mereka pun sudah menyadari perasaan tersebut sejak kecil. Pengalaman keduanya hamper serupa dengan pemaknaan yang sedikit berbeda, subjek SA merasa tidak nyaman dengan identitas biologisnya namun subjek RA merasa memiliki dua sifat dalam dirinya.

Melalui penelitian ini juga diperoleh temuan bahwa pada salah satu partisipan, kedekatan dengan Tuhan merupakan hal yang dapat dijadikan pegangan bagi dirinya untuk tidak melakukan hal-hal yang melanggar batas. Kedekatan dengan Tuhan ini juga yang menjaganya untuk tidak terlalu terbawa pada pemikiran "membuka diri" secara utuh (coming out maupun mengubah jenis kelaminnya).

Dari hasil penelitian ini, dapat dilihat bahwa konflik yang terjadi di dalam diri para transgender terkait perbedaan antara jenis kelamin biologisnya dengan identitas gendernya membuat kehidupan mereka menjadi lebih rumit. Dukungan dari lingkungan sangat dibutuhkan oleh para transgender agar dapat mengelola konflik tersebut dan tetap berfungsi secara optimal. Oleh karena itu, hal ini perlu menjadi perhatian para tenaga ahli pemerhati kesehatan mental untuk dapat membuat kelompok dukungan (support group) sebagai wadah berbagi yang sehat dan terkontrol. Selain itu, bila ada kelompok dukungan tersebut, para tenaga ahli juga dapat memberikan arahan, masukan serta penguatan untuk menjaga kesehatan mental para transgender.

\section{Ucapan Terima Kasih (Acknowledgement)}

Peneliti mengucapkan terima kasih kepada pihak-pihak yang telah menjadi jembatan antara peneliti dengan partisipan sehingga data dapat terkumpul untuk penelitian ini.

\section{REFERENSI}

Afrasiabi, H., \& Junbakhsh, M. (2019). Meanings and experiences of being transgender: a qualitative study among transgender youth. The Qualitative Report, 24(8), 1866- 1876.

Crooks, R., \& Baur, K. (2005). Our sexuality (9th ed). Wadsworth.

Detik Health (2010, April 14). Makin Banyak Orang Bingung dengan Jenis Kelaminnya. Diakses November 1, 2020. https://health.detik.com/berita-detikhealth/d1338393/makin-banyak-orang-bingung-dengan-jenis-kelaminnya.

Diamond, L. M., Pardo, S. T., \& Butterworth, M. R. (2011). Transgender experience and identity. In Handbook Of Identity Theory And Research (pp. 629-647).

Erikson, E. H. (1993). Childhood and society (2nd ed). Norton \& Company.

Fatmawati, F. (2019). Religiusitas waria di surabaya. Lakon: Jurnal Kajian Sastra dan Budaya, 8(2), 87-96. http://dx.doi.org/10.20473/lakon.v8i2.19778

Glock, C. Y., \& Stark, R. (1968). American piety: The nature of religious commitment (Vol. 1). Helgeson, V. S. (2012). Psychology of gender. Pearson.

Kristiana, T. W. A., \& Indrawati, E. S. (2018). Jalanan terjal sudah kujajal interpretative 
phenomenological analysis (IPA) tentang pengalaman stress coping pada transgender pasca coming out. Jurnal Empati, 6(3), 259-267.

King, M., McKeown, E., Warner, J., Ramsay, A., Johnson, K., Cort, C.,\& Davidson, O. (2003).

Mental health and quality of life of gay men and lesbians in England and Wales: controlled, cross-sectional study. The British Journal of Psychiatry, 183(6), 552-558.

Kumar, R. (2011). Research methodology: step-by-step guide for beginners (3rd ed). SAGE Publication.

Leary, M. R., \& Hoyle, R.H. (2009). Handbook of individual differences in social behavior. The Guildford Press.

Lestari, I., \& Sefitri, S. (2016). Konseling Bagi Populasi Transgender. Jurnal Konseling Gusjigang, 2(1).

Nevid, J. S., Rathus, S. A., \& Green, B. (2005). Psikologi abnormal.

Ningsih, E. S., \& Syafiq, M. (2014). Pengalaman menjadi pria transgender. Jurnal Penelitian Psikologi, 3(2), 1-6.

Poerwandari, E. K. (2013). Penelitian kualitatif untuk penelitian manusia. LPSP3UI.

Taylor, S. E., Peplau, L. A., \& Seas, D. O. (2009). Psikologi sosial (ed 2). Kencana. 